Научная статья

УДК 338(091)

DOI 10.18101/2304-4446-2021-4-3-9

\title{
КЯХТИНСКИЙ ФРОНТИР В ХVII-ХХІ ВЕКАХ: ОПЫТ ПРОРЫВНОГО РАЗВИТИЯ ПРЕДКОВ
}

\author{
(C) Атанов Николай Иванович \\ доктор экономических наук, профессор \\ Бурятский государственный университет имени Доржи Банзарова \\ Россия, 670000, г. Улан-Удэ, ул. Смолина, 24а \\ ni.atanov@yandex.ru
}

Аннотация. Город Кяхта и Кяхтинский район в целом известны своим уникальным географическим местоположением, которое в ходе исторического развития было расположено на пути прошествия экономического коридора, соединяющего страны Азии с Россией и далее - на запад. Автором в статье дана экспертная оценка развитию кяхтинского фронтира царского, советского и современного периодов, на основе которого сделан вывод, что будущее его развития без внешнего стимулирующего фактора не имеет перспектив. Таким триггером может стать экономический коридор «Китай - Монголия - Россия - Европа», идеи развития которого актуальны на межгосударственном уровне. В статье предложен пакет мер и действий, исполнение которых даст шанс для встраивания местных бизнесов в торговые цепочки экономического коридора.

Ключевые слова: фронтир, экономический коридор, шелковый путь, евразийский экономический союз, исторический опыт.

\section{Для цитирования}

Атанов Н. И. Кяхтинский фронтир в XVIII-XXI веках: опыт прорывного развития предков // Вестник Бурятского государственного университета. Экономика и менеджмент. 2021. № 4. C. 3-9.

Концентрация нового центра экономической активности и накопления капитала в азиатском континенте сопровождается активизацией торговоэкономических связей по оси Восток - Запад. Лидером выступает Китай с концепцией «Один пояс и один путь», реализующийся в двух проектах: морском и сухопутном. Балансиром однополярному гегемонизму Китая выступает Евразийский экономический союз на пространстве восточной части Европы.

Руководством России, Монголии и Китая продекларирована непротиворечивость и направленность проектов Евразийского экономического союза (ЕАЭС), Монголии - «Степной путь» и Китая — «Великий шелковый путь» (ВШП), подкрепленная совместной программой создания северного экономического коридора Китай - Монголия - Россия. Для российской стороны реализация программы начинается с Республики Бурятия, точнее - с Кяхтинского района: МАПП - Кяхта - Алтан-Булаг и железнодорожного пункта перехода - Наушки - Сухэ-Батор (Монголия).

Не будет преувеличением допущение о том, что объемы и скорость встраивания муниципальных экономик Республики Бурятия и других регионов Сибири в торгово-экономические цепочки вновь формирующегося евразийского общего 
рынка будут в определенной степени зависеть от пропускной способности, развитости экономики, производственной, транспортно-логистической и социальной инфраструктуры кяхтинского фронтира ${ }^{1}$.

Анализ социально-экономического положения Кяхтинского района и г. Кяхта свидетельствует о наличии громадных резервов в совершенствовании экстерьера и интерьера кяхтинского фронтира на пересечении Великого шелкового пути, степного пути и Евразийского экономического союза.

Первый - это значительный резервный потенциал развития, требующий кадровой и инвестиционной поддержки. Второй - это необходимость приращения мощностей и технологической оснащенности пограничных и таможенных терминалов в условиях возрастающих пассажиро- и грузоперевозок в обоих направлениях. Третий - это развитие приграничной инфрастуктуры: дорожнотранспортно-логистической; сервисного обслуживания. И, наконец, четвертый и основной - это необходимость реконструкции города Кяхта для возрождения его былого уровня социологического и торгово-купеческой славы.

В активе кяхтинцев бесценный капитал - исторический опыт и примеробразец предков - купцов, которые в XXVIII-XIX вв. сумели на диком и не освоенном пространстве Южного Забайкалья организовать центр российскокитайской сухопутной торговли и развить его до таких масштабов, что о Кяхте знало все мировое купечество.

Ретроспективный анализ российско-китайской сухопутной торговли, получившей название «Великий чайный путь», полезен для современных участников строительства экономического коридора «Китай — Монголия — Россия» в качестве путеводителя-справочника с «зелеными», «желтыми» и «красными» разметками.

История кяхтинского феномена имеет обширную библиографию. Наша задача заключается в извлечении из этих источников крупиц не только полезных практик, но и ошибочных решений и действий, их систематизация и обобщение на службу нового кяхтинского фронтира.

В основе основ - два документа, созданных благодаря профессиональной прозорливости, государственной мудрости, дипломатической терпеливости и настойчивости Саввы Лукича Владиславович-Рагузинского, направленного императрицей Екатериной II в 1725 г. послом России в Китай. Первый - это Буринский договор от 20 августа 1727 г., которым определена южная граница России с Китаем. Второй - это так называемый Кяхтинский трактат от 14 июня 1728 г., в котором среди прочих определены условия русско-китайской торговли

\footnotetext{
1 Этимологически понятие «фронтир» (англ. Frontier) означает «рубеж», «граница» (Тернер, 2009). Но в отличие от границы с ее разделяющей функцией фронтир имеет еще контактную функцию, т. е. пространство, в которое входит граница двух территорий, или переходная зона взаимодействия двух территорий или переходная зона взаимодействия двух и более культур и/или политико-экономических структур. Если в русской интерпретации «граница» означает «рубеж», то «фронтир» - «порубежье». Три функциональных значения фронтира - подвижность порубежья путем освоения новых земель; смешение и взаимодействие двух и более народов; формирование новой общности под влиянием эндогенных факторов: природно-климатических, экономико-политических; конфессионально-идеологических.
} 
Н. И. Атанов. Кяхтинский фронтир в XVIII-XXI веках: опыт прорывного развития предков

с переносом русского частного торга из Урги (ныне г. Улан-Батор, столица Монголии) и Цицикара (Северный Китай) в Кяхту и Цурухайту (ныне Приаргунский район Забайкальского края).

С тех пор кяхтинский фронтир стал стремительно осваиваться предприимчивыми людьми из Архангелогородской, Казанской, Костромской, Московской, Нижегородской, Симбирской, Ярославской, Томской, Иркутской и других губерний.

На китайском побережье всего в четверти километров от Кяхтинской слободы выходцы из провинции Шаньси в 1730 г. построили торговый город Маймачен. С этого момента начался 75-летний кяхтинский цикл российско-китайской торговли. К институциональным инновациям того периода, не потерявшим своей актуальности и ныне, следует отнести, во-первых, проектный подход, примененный в строительстве торговой слободы, создании генерального плана, включающего в себя гостиный двор с идеальной логистикой для гужевого транспорта, с оптимальной емкостью складских и торговых площадей, жилищнокоммунального сектора в компактной застройке. Создание локальной строительной базы обеспечило быстрое и качественное завершение строительства, основанного на ручном труде строителей.

«Токсичным» институтом на этапе становления торговли, спровоцировавшим уход в контрабанду, являлась узаконенная меновая торговля и госмонополия на меха, изделия из золота и серебра, развившаяся бюрократическая система. Выход из законодательной ловушки, найденный кяхтинцами, емко изложил писатель В. Распутин: «Кяхта - дитя торгового брака России с Китаем: между Слободой и китайским городом Маймачен никаких ограничений и никакого контроля в движении туда и обратно не существовало... Но по дороге из Троицкосавска в Слободу, из одного российского пункта в другой... стояла таможня, обыскивающая пешего и конного, его величество и его нижайшество. Искать логику в российских законах и всегда-то представляло немалые затруднения, а в середине прошлого века законами по отношению к Кяхте управляло одно упрямство. Торговлю обязывали быть только меновой: вы нам чай и «китайку» (бумажное полотно), мы вам меха, мануфактуру и кожи... Что оставалось кяхтинцам делать? От мала до велика они объединялись в контрабанде. Это было великое надувательство не расположенных к ним установлений, о котором все знали, все участвовали и все закрывали глаза, делая вид, что ничего противозаконного не происходит... И так продолжалось десятки лет, в которые Кяхта не только пострадала, а наоборот, расцвела...» (Распутин, 1985:9).

Отмена меновой торговли в 1860 г. в России и наделение Кяхтинской слободы статусом зоны беспошлинной торговли дало торговле экспоненциальный рост и Кяхту стали величать «Вольным городом», «Золотыми воротами России», «Песчаной Венецией» и т. д.

Еще одним важным инструментом, давшим ускорение социальному развитию г. Троицкосавска и Кяхтинской слободы, подъему культурно-цивилизационного уровня их жителей, являлось становление местного самоуправления с широким диапазоном свободы. Создание института муниципально-частного/купеческого партнерства воздвигло Кяхту в образовательно-культурный центр России на всем зауральском пространстве. В подтверждение приведем несколько примеров. 
Местное самоуправление и общественность в приоритеты выдвинули образование подрастающего поколения и просветительскую работу среди взрослого населения. В течение XIX в. было создано 14 учебных заведений, многие из которых были частными, в том числе женская гимназия, школа обучения китайскому языку, сиропитательная школа (аналог ремесленного училища) и др.

Первая общественная библиотека с читальным залом открылась в 1887 г., где взрослое население организовывало различные просвещенческие кружки, диспуты, семинары, публичные лекции. Развивались любительский театр и публичное музицирование. Большим событием стало открытие кинотеатра (1910-1911 гг.).

Научному развитию Кяхты способствовали исследовательские экспедиции в Центральную Азию. Последствием пребывания их в Кяхте стало открытие краеведческого музея (1980), отделения Русского географического сообщества (1894) По инициативе отделения в Кяхте была создана первая метеостанция.

Параллельно развивалось здравоохранение. В 1820-х гг. построена гражданская больница, в 1860-1870-х гг. - лечебница им. Александра I, численность врачей, фельдшеров и акушеров составляла 51 чел.

На средства купечества и жителей построены соборы: Успенская, Никольская, Покровская, Михайловская с богатым и пышным убранством. Основная причина упадка и свертывания сухопутной российско-китайской торговли через кяхтинский фронтир известна - это технический прогресс, а именно: создание парового двигателя, установленного на морские суда и железнодорожные локомотивы. Ясно, что гужевой транспорт никак не мог конкурировать с транспортными средствами на паровой тяге ни по грузоподъемности, ни по скорости, ни по стоимости перевозок. Открытие Суэцкого канала лишь послужило триггером, ускорившим перегрузку транспортных маршрутов. «Та же судьба, которая постигла красавицу Адриатики - Венецию, обрученную с морем, судьба мгновенного величия и могущества, а затем падения, тяготела над степной сибирской Венецией» (Ядринцев, 1894: 110).

Культурно-цивилизационный бум Кяхты начал замедляться вслед за торговлей. В советский период развитие кяхтинского фронтира происходило по другой парадигме и иным сценариям. Главенствующими приоритетами были индустриализация промышленности и развитие сельского хозяйства с государственной и кооперативной формами собственности. Роль фронтира занимала второстепенные позиции. Приграничное сотрудничество ограничивалось сельским хозяйством на принципах меновой торговли. К положительным практикам следует отнести функционирование сезонных/временных пунктов перехода государственной границы. Безвизовый режим перехода границы гражданами фронтира способствовал наполнению практическим содержанием потенциала «народной дипломатии». Попытка кяхтинских купцов проложить железную дорогу на Кяхту от ст. Мысовая в 1900-х г. была осуществлена в 1948 г. по маршруту ст. Заудинск - Наушки.

Кяхтинский гостиный двор купеческой слободы в 1958 г. был перестроен под прядильно-трикотажную фабрику, работающую на хлопке - сырье из Узбекистана. В начале 1980-х гг. фабрика открыла филиал в соседней Монголии г. Дархан. С распадом СССР поставки хлопка прекратились и фабрика, с 1200 рабочими местами, закрылась. 
Н. И. Атанов. Кяхтинский фронтир в XVIII-XXI веках: опыт прорывного развития предков

В районе действовали плавико-шпатовый комбинат, комбикормовый завод, поставлявший корма для свинокомплекса, овцеводства и крупного рогатого скота, маслосыродельный и молочный комбинаты, пивоваренный и хлебозавод, которые повторили судьбу сельхозугодий.

Тридцатилетняя новейшая история постсоветской России характеризуется следующими изменениями и новшествами в развитии кяхтинского фронтира. Произошла фрагментизация хозяйствующих субъектов вследствие разгосударствления и приватизации активов совхозов, колхозов, промышленных и инфраструктурных объектов. В результате распалась сетка кооперационных взаимосвязей между предметно и технологически сопряженными субъектами вновь формируемого рынка, что обернулось чередой банкротств. Законы рынка неумолимо сработали в направлении очистки его от несостоятельных факторов. В итоге сумма результатов фрагментированного частного перманентно стала значительно меньше общего целого. Другими словами, благая цель достижения рыночного благополучия привела к противоположным результатам. Экономику личных подворий и единых крестьянских (фермерских) хозяйств, конечно, некорректно сравнивать с экономикой 16 колхозов и совхозов. Состояние промышленных объектов характеризует сравнение с XIX в. «Главными причинами неразвитости фабрично-заводской промышленности были отсутствие дешевых рабочих рук и дороговизна получения необходимых машин и материалов из европейской части России. Среди промышленных предприятий можно выделить кожевенный завод на реке Чикой..., три винокуренных завода, десять мелких заводов в Усть-Кяхте, три мельницы крупчатого помола, несколько мыловаренных и свечных заводов. В окрестностях Кяхты действовал стеариновый завод... Ремесленное дело получило слабое развитие по причине того, что в сравнении с чайным бизнесом оно проигрывало по доходности» (Необычайная Кяхта, 2013:31).

На 1 января 2021 г. в районе нет действующих промышленных предприятий. Единственный Кударинский маслосырозавод уже третий год не могут запустить из-за организационных неурядиц и финансовых затруднений. Другими словами, современный Кяхтинский район в уровне своего развития регрессировал до состояния начала XIX в.

При сохранении тенденций настоящего времени рассчитывать на быстрый перелом стагнации в экономике кяхтинского фронтира не приходится. Особенно с учетом ухудшающегося демографического положения. «Встряску» может дать только внешний раздражитель - стимулятор, коим может стать экономический коридор Китай - Монголия - Россия, утвержденный лидерами трех стран в 2016 г. Запаздывание по срокам исполнения программы пока выгодно местному бизнесу, поскольку степень его готовности и готовности институтов к встраиванию в торгово-экономические цепочки будущего экономического коридора близка к нулю.

По нашему мнению, отсутствие превентивной подготовительной работы может привести к тому, что вместо врастания в цепочки экономического коридора муниципальные районы вдоль него окажутся в роли современных площадок для обслуживания проносящегося мимо экономического экспресса. Подготовительную работу необходимо организовывать, учитывая следующие вопросы: на каких языках придется вести деловые диалоги с потенциальными иностранными 
партнерами: русском, китайском, корейском, монгольском, английском, японском; каков уровень профессиональной компетенции местного делового сотрудничества, включая знания правовой и нормативной базы международной торговли и соседних стран; какова величина и структура экспортного и конкурентного потенциала муниципальной и региональной экономики; какова степень готовности муниципального и регионального правового, нормативного, институционального, инфраструктурного и информационного обеспечения для создания зоны свободной торговли в Кяхтинском фронтире (Атанов Н. И, Цыремпилов В. Ж., с. 228).

Ответ на третий вопрос следует искать в двух направлениях. Первое - создание в Республике Бурятия исследовательско-аналитического маркетингового центра для изучения рынков стран на новом Шелковом пути, а также экономик соседних регионов России на предмет кооперации для суммирования экспортных и конкурентных потенциалов. Второе направление - определение экспортной специализации каждого муниципального образования и принятие мер по наращиванию его потенциала.

Четвертый вопрос можно решить в союзе: город Кяхта - Кяхтинский район - Республика Бурятия - федеральный центр - бизнес. При этом следует апеллировать на исторический факт - наделение Кяхтинской торговой слободы статусом «зоны беспошлинной торговли», а также на уже созданную зону свободной торговли в сопредельной Монголии - г. Алтан-Булаг.

Модернизация инфраструктурной базы не ограничивается автомобильным и железнодорожным транспортом. Актуально создание водного трансграничного транспортного коридора по реке Селенга, а также воздушного сообщения. Необходимо строительство аэродромного комплекса для открытия местных и региональных воздушных сообщений, в т. ч. с Монголией, Китаем, Южной Кореей и др.

Развертка каждого пункта - это отдельная программная проработка не только для Кяхтинского района, а всех муниципальных субъектов в Республике Бурятия и соседних регионах.

\section{Литература}

1. Атанов Н. И., Цыремпилов В. Ж. История, современность и перспективы развития кяхтинского фронтира // Россия и Монголия в XX-XXI вв.: к 100-летию монгольской революции и установления дипломатических отношений: сборник научных статей / науч. ред. В. Н. Пармон, Б. В. Базаров, редкол. А. М. Плеханова и др.; Правительство Республики Бурятия. Новосибирск: Изд-во СО РАН, 2021. С. 225-229. Текст: непосредственный.

2. Голомолзин А. Н. Познать истину. Москва: Букстар, 2016. 864 с. Текст: непосредственный.

3. Необычайная Кяхта / автор-сост. Л. Б. Цыденова. Улан-Удэ: НоваПринт, 2013. 200 с: ил. Текст: непосредственный.

4. Распутин В. Кяхта // Огонек. 1985. № 22. С. 9. Текст: непосредственный.

5. Тернер Ф. Фронтир в американской истории / пер. с англ. А. И. Петренко. Москва: Весь мир, 2009. 340 с. Текст: непосредственный.

6. Ядринцев М. Н. На границах Китая (из путевых очерков) // Книжки недели. 1984. № 7. С. 110-129. Текст: непосредственный. 
Н. И. Атанов. Кяхтинский фронтир в XVIII-XXI веках: опыт прорывного развития предков

Статья поступила в редакцию 20.10.2021; одобрена после рецензирования 29.10.2021; принята к публикации 01.11.2021.

KYAKHTA FRONTIER IN THE $18^{\text {th }}-21^{\text {st }}$ CENTURIES: THE EXPERIENCE OF THE ANCESTORS' BREAKTHROUGH

Nikolay I. Atanov

Dr. Sci. (Econ.), Prof.,

Dorzhi Banzarov Buryat State University

24a Smolina St., Ulan-Ude 670000, Russia

ni.atanov@yandex.ru

Abstract. The town of Kyakhta and Kyakhta District are known for their unique geographic location on the way of the economic corridor connecting the countries of Asia with Russia and further to the west. In the article we gave an expert assessment of the development of Kyakhta frontier in the tsarist, Soviet and modern periods, and concluded that its future development without external stimulating factors has no prospects. China - Mongolia Russia - Europe Economic Corridor could become such a trigger. The ideas for its development are particularly relevant at the interstate level. The article proposes a set of measures, which could give a chance for embedding local businesses in the trade chains of the economic corridor.

Keywords: frontier, economic corridor, Silk Road, Eurasian Economic Union, historical experience.

For citation

Atanov N. I. Kyakhta Frontier in the 18th-21st Centuries: The Experience of the Ancestors' Breakthrough. Bulletin of Buryat State University. Economy and Management. 2021; 4: 3-9 (In Russ.).

The article was submitted 20.10.2021; approved after reviewing 29.10.2021; accepted for publication 01.11.2021. 